\title{
Pelatihan Penulisan Karya Tulis Ilmiah (KTI) Bagi Guru-guru SMK di Kabupaten Jombang
}

\author{
Renny Dwijayanti \\ Universitas Negeri Surabaya, Indonesia, rennydwijayanti@unesa.ac.id \\ Novi Marlena \\ Universitas Negeri Surabaya, Indonesia, novimarlena@unesa.ac.id \\ Finisica Dwijayati Patrikha \\ Universitas Negeri Surabaya, Indonesia, finisicapatrikha@unesa.ac.id \\ Parjono \\ Universitas Negeri Surabaya, Indonesia, parjono@unesa.ac.id
}

\begin{abstract}
Professional teachers not only perform functions related to pedagogical competence, but also professional functions. Indicated by improve professional functions in writing scientific papers. This Community Service collaborates with two partners, which are teachers who are member of MGMP Office Administration and teachers in SMKN 1 Jombang. The aim of this Community Service is to train teachers to write scientific papers well, and publish their papers as well. These activities conducted in training activity, lecturing, question and answer, discuss and practice how to write scientific papers well. The result of these activities is 1) the implementation of this scientific writing training for vocational high school teachers is consistent to the steps that planned before, with two partners, which are teachers who are member of MGMP Office Administration and teachers in SMKN 1 Jombang, 2) the overall response from the participants of this scientific writing trainingare very satisfied, mainly because of the aspects of activities, speaker's aspects, and general aspects.
\end{abstract}

Keywords: Scientific Paper, Teacher, Professional functions

\section{PENDAHULUAN}

\section{Analisis Situasi}

Kemampuan menulis harus

dimiliki oleh setiap orang yang bergerak

di dunia pendidikan. Menulis

merupakan kegiatan komunikasi berupa penyampaian ide, gagasan, perasaan, kehendak, pesan secara tertulis kepada pihak lain. Penulisan karya ilmiah Available at http://journal.unj.ac.id/unj/index.php/jpm adalah sebuah karya tulis yang penyusunannya di dasarkan pada kajian ilmiah dengan landasan ilmu pengetahuan tertentu.

\begin{tabular}{l}
\multicolumn{2}{c}{ Penulisan karya ilmiah } \\
merupakan kegiatan yang sangat \\
penting bagi seorang guru yang \\
profesional. Penulisan karya ilmiah
\end{tabular}


tidak saja perlu dilakukan dalam rangka memperoleh angka kredit untuk kenaikan jabatan atau untuk keperluan sertifikasi melalui portofolio, tetapi terlebih lagi perlu dilakukan dalam rangka peningkatan kualitas pengelolaan kelas, kualitas layanan kepada anak didik, dan juga peningkatan profesionalisme guru itu sendiri.

Guru adalah jabatan profesi sehingga seorang guru harus mampu melaksanakan tugasnya secara profesional. Seseorang dianggap professional apabila mampu mengerjakan tugas dengan selalu berpegang teguh pada etika profesi, independen, produktif, efektif, efisien dan inovatif serta didasarkan pada prinsip-prinsip pelayanan prima yang didasarkan pada unsur-unsur ilmu atau teori yang sistematis, kewenangan profesional, pengakuan masyarakat, dan kode etik yang regulative.

Tulisan ilmiah yang berisi hasil penelitian, hasil pengkajian, hasil pemikiran, dan karya guru lainnya, sangat potensial sebagai wahana komunikasi dan diseminasi karya dan ide kepada guru atau orang lain. Guru yang profesional tidak hanya melakukan fungsi terkait dengan kompetensi pedagogis (khususnya merencana, melakukan, menilai dan mengadministrasi pembelajaran), tetapi juga fungsi yang terkait dengan kompetensi kepribadian, sosial, serta keprofesionalan, yang antara lain ditandai dengan peningkatan diri melalui menulis karya ilmiah. Oleh karena itu, setiap guru sudah semestinya mau, mampu, dan biasa melakukan kegiatan penulisan karya ilmiah. Pemaparan karya ilmiah harus sistematis, logis dan cermat dalam segala aspek termasuk juga aspek bahasa. Kriteria karya ilmiah harus bersifat objektif, rasional dan tidak emosional berdasarkan fakta dan tersusun secara sistematik dan runtut (Maryadi, 2002).

Karya tulis ilmiah guru hendaknya memiliki persyaratan khusus, yakni syarat APIK (Asli, Perlu, Ilmiah, dan Konsisten) (Arikunto, 2007:83) yang artinya adalah: (1) Asli, karya tulis yang dihasilkan harus merupakan produk asli guru dan sesuai dengan mata pelajaran yang diampu dan tempat bekerja. (2) Perlu, karya tulis 
yang dihasilkan guru harus dirasakan manfaatnya secara langsung oleh guru dalam meningkatkan kualitas pembelajaran. (3) Ilmiah, karya tulis yang dihasilkan harus disusun secara ilmiah, sistematis, runtut dan memenuhi persyaratan penulisan karya ilmiah, dan (4) Konsisten, karya tulis ilmiah yang dihasilkan harus memperlihatkan keajegan dan konsistensi pemikiran yang utuh, baik secara keseluruhan maupun hubungan antar bab bagian karya tulis yang disajikan.

Karya tulis ilmiah penting tidak hanya sebagai salah satu syarat kenaikan pangkat dari golongan IV/a ke IV/b sampai IV/e, teristimewa penting bagi profesionalisme guru dalam pembelajaran. Dengan KTI seorang guru diharapkan mampu mengadakan penelitian di kelas dalam bentuk Penelitian Tindakan Kelas (PTK), terlebih lagi guru bisa menemukan atau menciptakan media teknologi pembelajaran yang bermanfaat bagi peningkatan mutu pendidikan.

Berdasarkan hasil observasi melalui wawancara terbatas dengan Kepala Dinas Pendidikan Kabupaten Jombang Bapak drg. Budi Nugroho,
MPPM, pada ruang lingkup Diknas Kabupaten Jombang menunjukkan betapa masih sedikitnya guru SMK yang mau, mampu, dan biasa melakukan kegiatan penulisan karya ilmiah. Dari banyak guru yang ada, hanya puluhan saja yang telah menunjukkan kemampuan, kemauan, dan kebiasaan menulis ini. Ini ditandai dari kemampuan mereka mencapai IVb dan kemunculan beberapa tulisan pada majalah atau terbitan lainnya. Sebagian terbesar guru masih merasa berat dan sulit untuk menulis. Beberapa hasil pengamatan dan wawancara kepada beberapa guru, banyak memberikan kejelasan mengapa guru belum mampu, mau, dan biasa menulis ilmiah. Dua aspek atau faktor dari sekian faktor yang muncul dari pengamatan dan wawancara ini adalah motivasi dan substansi. Aspek motivasi, terkait dengan belum munculnya minat, semangat, dan keinginan kuat dari para guru untuk memulai menulis karya ilmiah. Bahkan secara tegas, sebagian besar Guru menyatakan puas sampai pada golongan IVa saja, manakala untuk naik ke IVb harus menulis karya ilmiah. Beberapa alasan penyebab 
rendahnya motivasi menulis karya ilmiah ini adalah ketakutan dan atau kecemasan menulis terkait dengan prosedur dan kriteria tulisan yang dapat diterima dan dihargai sebagai karya ilmiah. Sebagian terbesar mereka menyatakan bahwa prosedur pembuatan karya ilmiah dan kriteria itu terlalu sulit untuk mereka penuhi atau ikuti. Sementara aspek substansi, terkait dengan isi atau bahan tulisan. Sebagian besar dari guru yang belum mau, mampu, dan biasa menulis, lebih disebabkan belum atau tidak adanya bahan yang layak untuk ditulis. Mereka menyatakan belum mempunyai waktu untuk melakukan penelitian, dan mencari sumber-sumber bacaan untuk ditulis, disamping itu kesibukan pekerjaan yang bersifat administratif yang berkaitan dengan pekerjaan akademis seperti menyusun RPP, pengelolaan kelas berbasis K13, serta beberapa pekerjaan administratif lainnya yang menjadi salah satu alas an mengapa guru enggan menulis karya ilmiah

\section{Perumusan Masalah}

Berdasarkan pada analisis situasi diatas, maka dapat diidentifikasi permasalahan kelemahan pemahaman dan kemampuan guru dalam menulis karya ilmiah yang pada akhirnya dapat meningkatkan pemahaman dan kemampuan menulis sebuah artikel ilmiah yang baik dan benar bagi guru di SMK di Jombang

\section{Tujuan dan Manfaat}

Adapun tujuan penelitian ini adalah untuk mengetahui kelemahan pemahaman dan kemampuan kemampuan guru dalam menulis karya ilmiah. Sementara manfaat kegiatan ini adalah untuk memberikan pemahaman dan kemampuan kemampuan guru dalam menulis karya ilmiah

\section{KAJIAN TEORITIK}

\section{Karya Tulis Ilmiah}

Karya tulis ilmiah adalah sebuah karya tulis yang disajikan secara ilmiah dalam sebuah forum atau media ilmiah. Karakteristik keilmiahan sebuah karya terdapat pada isi, penyajian, dan bahasa yang digunakan. (Djuroto, 2014:117). Isi karya ilmiah tentu bersifat keilmuan, yakni rasional, objektif, tidak memihak, dan berbicara apa adanya. Isi sebuah karya ilmiah harus fokus dan bersifat spesifik pada sebuah bidang keilmuan 
secara mendalam. Kedalaman karya tentu sangat disesuaikan dengan kemampuan sang ilmuwan. Bahasa yang digunakan juga harus bersifat baku, disesuaikan dengan sistem ejaan yang berlaku di Indonesia. Bahasa ilmiah tidak menggunakan bahasa pergaulan, tetapi harus menggunakan bahasa ilmu pengetahuan, mengandung hal-hal yang teknis sesuai dengan bidang keilmuannya.

Menurut Rif'an

Sebuah karya tulis yang baik tentu yang komunikatif, maksudnya pesan yang disampaikan dipahami pembaca sebagaimana maksud penulis. Tulisan yang komunikatif disampaikan melalui bahasa-bahasa yang tersusun sistematis, mudah dicerna, tidak bertele-tele, dan tidak bermakna ganda (ambigu). Menulis karya ilmiah, dengan bahasa lain, adalah menyusun kalimat-kalimat bermakna dalam sebuah rangkaian informasi yang berguna untuk pembaca.

Fungsi utama karya ilmiah adalah fungsi akademik. Melalui karya ilmiah terjalin komunikasi akademik antarberbagai komponen dalam sebuah bidang keilmuan. Seorang guru akan mengetahui model-model terbaru dalam pembelajaran bahasa apabila membaca jurnal ilmiah atau tulisan dari berbagai sumber. Demikian pula apabila menuliskan temuannya, guru yang lain akan mengetahui hasil penelitian guru yang lain. (Maryadi, 2002:103)

Fungsi lainnya adalah sebagai fungsi ekpresif dan fungsi instrumental. Fungsi ekspresif adalah seseorang dapat menuangkan berbagai gagasan tertulis yang dikomunikasikan kepada pihak lain. Menulis berdasarkan fungsi ini adalah usaha pemenuhan kebutuhan diri seseorang sebagai ilmuwan atau sebagai manusia yang berpikir. Sementara itu, fungsi instrumental adalah bahwa menulis menjadi media bagi seseorang untuk meraih tujuan-tujuan lainnya. (Soehardjono, 2012)

Menurut Soehardjono (2006) laporan penelitian harus memenuhi kriteria kriteria -APIK, yakni asli, penelitian harus merupakan karya asli penyusunnya, bukan merupakan plagiat, jiplakan, atau disusun dengan niat dan prosedur yang tidak jujur. Syarat utama karya ilmiah adalah kejujuran. Ilmiah, penelitian harus berbentuk, berisi, dan dilakukan sesuai dengan kaidah-kaidah kebenaran ilmiah. Penelitian harus 
benar, baik teorinya, faktanya maupun analisis yang digunakannya. Konsisten, penelitian harus disusun sesuai dengan kemampuan penyusunnya. Bila penulisnya seorang guru, maka penelitian haruslah berada pada bidang kelimuan yang sesuai dengan kemampuan guru tersebut.

Adapun ruang lingkup kegiatan karya tulis/karya ilmiah (KTI) di bidang pendidikan, meliputi: karya ilmiah (laporan dan atau artikel) hasil penelitian, pengkajian, survei dan atau evaluasi di bidang pendidikan, karya tulis berupa tinjauan atau ulasan ilmiah gagasan sendiri dalam bidang pendidikan, tulisan ilmiah populer, prasaran dalam pertemuan ilmiah, buku pelajaran, diktat pelajaran dan karya alih bahasa atau karya terjemahan. Kegiatan membuat alat pelajaran/alat peraga atau alat bimbingan, meliputi pembuatan alat peraga dan alat bimbingan. Kegiatan menciptakan karya seni meliputi karya seni sastra, lukis, patung, pertunjukan, kriya, dan sejenisnya. Kegiatan menemukan teknologi tepat guna di bidang pendidikan meliputi teknologi yang bermanfaat di bidang pembelajaran, seperti alat praktikum, dan alat bantu teknis pembelajaran. Sementara itu, kegiatan pengembangan kurikulum meliputi keikutsertaan dalam penyusunan standar pendidikan dan pedoman lain yang bertaraf nasional.

\section{Jurnal Ilmiah}

Jurnal ilmiah adalah majalah publikasi yang memuat KTI (Karya Tulis Ilmiah) yang secara nyata mengandung data dan informasi yang mengajukan iptek dan ditulis sesuai dengan kaidah-kaidah penulisan ilmiah serta diterbitkan secara berkala. (Djuroto, 2014:121).

Jurnal ilmiah wajib memenuhi persyaratan administratif sebagai berikut : 1) Memiliki International Standard Serial Number (ISSN), 2) Memiliki mitra bestari paling sedikit 4 (empat) orang, 3) Diterbitkan secara teratur dengan frekuensi paling sedikit dua kali dalam setahun, kecuali majalah ilmiah dengan cakupan keilmuan spesialisasi dengan frekuensi satu kali dalam satu tahun, 4) Bertiras tiap kali penerbitan paling sedikit berjumlah 300 eksemplar, kecuali majalah ilmiah yang menerbitkan sistem jurnal elektronik $(e-$ journal) dan majalah ilmiah yang 
menerapkan sistem daring (online) dengan persyaratan sama dengan persyaratan majalah ilmiah tercetak, 5) Memuat artikel utama tiap kali penerbitan berjumlah paling sedikit 5 (lima), selain dapat ditambahkan dengan artikel komunikasi pendek yang dibatasi paling banyak 3 (tiga) buah. (Djuroto, 2014:98)

\section{Kompetensi Guru}

Menurut Jejen (2011:56) Kompetensi merupakan seperangkat pengetahuan, keterampilan, dan prilaku yang harus dimiliki, dihayati, dikuasai, dan diwujudkan oleh guru dalam melaksanakan tugas keprofesionalan dan ditampilkan melalui unjuk kerja. Mentri Pendidikan Nasional melalui keputusannya nomor 045/U/2002 menyebutkan kompetensi sebagai seperangkat tindakan cerdas dan penuh tanggung jawab dalam melaksanakan tugas-tugas sesuai dengan pekerjaan tertentu. Sehingga komptensi guru dapat diartikan sebagai kebulatan pengetahuan, keterampilan dan sikap yang terwujud tindakan cerdas dan penuh tanggung jawab dalam melaksanakan tugas sebagai agen pembelajaran.

$$
\text { Menurut Hakim }
$$
kompetensi yang harus dimiliki oleh guru meliputi kompetensi pedagogik, profesional, sosial dan personal. Pertama, kompetensi pedagogik merupakan kemapuan guru dalam pengelolaan pembelajaran peserta didik yang sekurang-kurangnya meliputi: (a) pemahaman wawasan atau landasan kependidikan, (b) pemahaman terhadap peserta didik, (c) pengembangan kurikulum atau silabus, (d) perancangan pembelajaran, (e) pelaksanaan pembelajaran yang mendidik dan dialogis, (f) pemanfaatan teknologi pembelajaran, (g) evaluasi hasil belajar; dan (h) pengembangan peserta didik untuk mengaktualisasikan.

Kedua, kompetensi profesional merupakan kemampuan Guru dalam menguasai pengetahuan bidang ilmu pengetahuan, teknologi, dan/atau seni dan budaya yang diampunya yang sekurang-kurangnya meliputi penguasaan: (a) materi pelajaran secara luas dan mendalam sesuai dengan standar isi program satuan pendidikan, mata pelajaran, dan/atau kelompok mata 
pelajaran yang akan diampu; dan (b) konsep dan metode disiplin keilmuan, teknologi, atau seni yang relevan, yang secara konseptual menaungi atau koheren dengan program satuan pendidikan, mata pelajaran, dan/atau kelompok mata pelajaran yang akan diampu.

Ketiga, kompetensi professional adalah kemampuan guru dalam komunikasi secara efektif dengan peserta didik, sesama pendidik, tenaga kependidikan, orang tua/wali, dan masyarakat. untuk berkomunikasi dan pengembangan diri. Kompetensi sosial merupakan kemampuan guru sebagai bagian dari masyarakat yang sekurangkurangnya meliputi kompetensi untuk: (a) berkomunikasi lisan, tulis, dan/atau isyarat secarasantun, (b) menggunakan teknologi komunikasi dan informasisecara fungsional, (c) bergaul secara efektif dengan peserta didik, sesamapendidik, tenaga kependidikan, pimpinan satuan pendidikan, orang tua atau wali peserta didik, (d) bergaul secara santun dengan masyarakat sekitar dengan mengindahkan norma serta sistem nilaiyang berlaku; dan (e) menerapkan prinsip persaudaraan sejati dan semangat kebersamaan.

Keempat, kompetensi terakhir adalah kompetensi kepribadian merupakan kemampuan personal guru yang mencerminkan kepribadian yang mantap, stabil, dewasa, arif dan berwibawa, menjadi teladan bagi peserta didik dan berahlak mulia.

\section{MATERI DAN METODE}

\section{Kerangka Pemecahan Masalah}

\section{Realisasi Pemecahan Masalah}

Kegiatan PKM KTI ini dilaksanakan pada tanggal 18 Agustus 2017 bertempat di SMK Negeri 1 Jombang J1. Dr. Sutomo No. 15 Kabupaten Jombang.

\section{Khalayak Sasaran}

Kegiatan PKM ini diikuti dua mitra yaitu guru yang tergabung dalam MGMP Administrasi Perkantoran dan guru SMKN 1 Jombang yang berjumlah 55 orang.

Materi yang disampaikan dalam PKM ini antara lain: (a) Kriteria Penulisan karya tulis ilmiah, (b) Bentuk dan tujuan penulisan karya tulis ilmiah, (c) Sistematika penulisan Karya Tulis Ilmiah, (d) Menyusun Jurnal Ilmiah. 
Metode

Kegiatan PKM ini dilakukan dalam bentuk pelatihan dengan metode bervariasi yaitu ceramah, tanya jawab, diskusi dan praktek penulisan karya tulis ilmiah sebagai upaya untuk meningkatkan kualitas kemampuan penulisan karya tulis ilmiah secara sistematis. Pelaksanaan PKM KTI ini adalah sebagai berikut: 1) Masingmasing guru yang akan menempuh pelatihan harus membawa draft karya ilmiah. 2) Guru diberikan materi pelatihan. 3) Menyediakan buku pedoman tentang penulisan Karya Tulis Ilmiah yang berupa handout agar memudahkan peserta dalam hal ini adalah guru-guru dalam memahami materi.

\section{HASIL DAN PEMBAHASAN}

1. Pelaksanaan Pelatihan Penulisan Karya Tulis Ilmiah Bagi Guru-Guru SMK di Jombang

Hasil kegiatan PKM secara garis besar mencakup beberapa komponen sebagai berikut: 1) Keberhasilan target jumlah peserta seperti direncanakan sebelumnya adalah paling tidak 25 guru di SMK
Negeri 1 Jombang. Dalam pelaksanaannya, kegiatan ini diikuti oleh 55 orang peserta. Dengan demikian dapat dikatakan bahwa target peserta tercapai 100\%. Angka tersebut menunjukkan bahwa kegiatan PKM dilihat dari jumlah peserta yang mengikuti dapat dikatakan berhasil/ sukses. 2) Ketercapaian tujuan pelatihan pendampingan penulisan artikel jurnal ilmiah secara umum sudah baik. Hal ini dilihat dari hasil latihan para peserta yaitu ada beberapa kualitas artikel jurnal ilmiah yang dapat dipertimbangkan untuk bisa masuk dalam jurnal ilmiah, maka dapat disimpulkan bahwa tujuan kegiatan ini dapat tercapai. 3) Ketercapaian target materi pada kegiatan PKM ini cukup baik, karena materi pendampingan telah dapat disampaikan secara keseluruhan. Kemampuan peserta dalam penguasaan materi. 4) Pada tahap pelaksanaan PKM KTI ini dapat dideskripsikan sebagai berikut materi pertama yang disampaikan dalam kegiatan PKM ini adalah pengertian dan karakteristik KTI dipaparkan 
oleh Novi Marlena, S. Pd, M.Si. Selanjutnya materi kedua tentang bentuk dan tujuan penulisan KTI dipaparkan oleh Renny Dwijayanti, S. Pd, M.Pd. Setelah itu dilanjutkan oleh Dr. Parjono, M. Si dengan materi sistematika penulisan KTI dan tips dan trik membuat KTI. Dan materi terakhir tentang penyusunan dan penilaian KTI disampaikan oleh Finisica D Patrikha, S. Pd, M.Pd. Setelah kegiatan penyampaian materi, tanya jawab dan diskusi selesai, kegiatan yang dilakukan adalah melakukan pendampingan tim dengan melakukan review hasil dari hasil perbaikan artikel ilmiah yang telah dibawa sebelumnya.

2. Pemahaman guru terkait dengan teknik penulisan KTI

Proses
dilaksanakan selama pelatihan
berlangsung yaitu dengan cara
melakukan review artikel ilmiah
yang sudah ada yang dibawa oleh
beberapa guru. Dari sisi konten
materi dilihat apakah sudah dengan
kaidah teori yang ada, serta dari sisi
gaya penulisan apakah gaya

Available at

http://journal.unj.ac.id/unj/index.php/jpm penulisan sudah sesuai dengan yang diminta oleh pengelola jurnal. Pada proses pembimbingan juga dikenalkan gaya selingkung jurnal pendidikan Ekonomi Kewirausahaan dan Keuangan (JPEKA), karena salah satu anggota PKM adalah pengelola jurnal maka audiens diminta untuk menyusun artikel dan memperbaikinya sesuai dengan gaya penulisan yang diminta.

Untuk mengevaluasi pelaksanaan kegiatan PKM KTI ini dilakukan dengan menyebarkan angket. Guru diminta mengisi angket respon dari kegiatan pelatihan yang telah dilakukan oleh tim pelaksana PKM. Hasil dari angket respon tersebut dianalisis dan selanjutnya dideskripsikan. Pendeskripsian respon dibagi menjadi 3 aspek, yaitu aspek pelaksanaan kegiatan, aspek narasumber, aspek umum yang dapat dijabarkan sebagai berikut:

Aspek pertama adalah aspek pelaksanaan kegiatan. Tiap-tiap komponen dalam aspek akan dijabarkan dalam gambar dibawah ini.

1) Aspek Pelaksanaan Kegiatan 
Komponen pertama adalah komponen kualitas paparan awal kegiatan Jabaran mengenai komponen tersebut ada pada gambar di bawah ini.

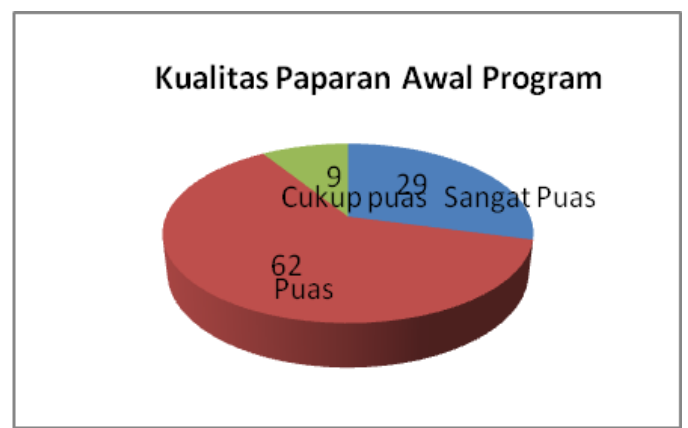

Gambar 1 Kualitas Paparan Awal Program

Berdasarkan diagram di atas dapat dilihat bahwa respon peserta pelatihan terkait dengan kualitas paparan awal program, peserta pelatihan yang merasakan sangat puas sebanyak $29 \%$, merasa puas sebanyak $62 \%$, dan cukup puas $9 \%$.

Overview yang disampaikan oleh ketua PKM mengenai gambaran pelatihan penulisan karya ilmiah yang dapat dipublikasikan di jurnal imiah sangat membantu guru untuk mengambil rencana tindakan untuk memperbaiki tulisan ilmiah yang telah dibawa sebelumnya.

Komponen kedua adalah komponen kesesuainan materi dengan

Available at

http://journal.unj.ac.id/unj/index.php/jpm tujuan. Jabaran mengenai komponen tersebut ada pada gambar di bawah ini.

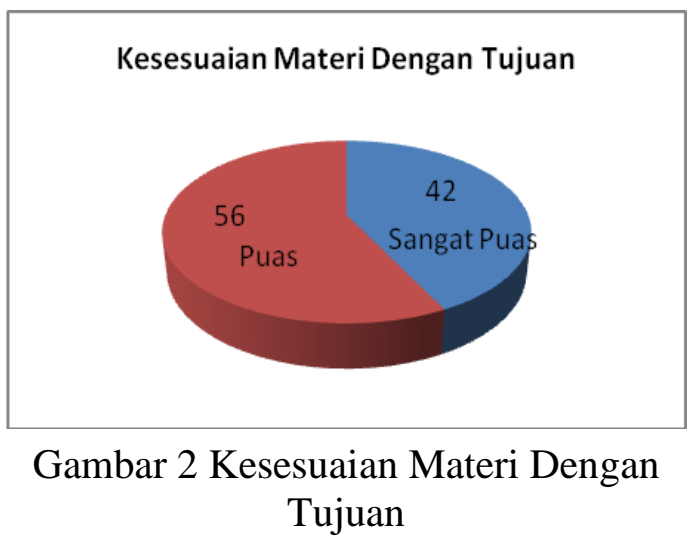

Berdasarkan diagram di atas dapat dilihat bahwa respon peserta pelatihan terkait dengan kesuaian materi dengan tujuan dalam pelatihan peserta pelatihan yang merasakan sangat puas sebanyak $42 \%$ dan merasa puas sebanyak $56 \%$.

Materi yang disampaikan antara lain: 1) pengertian dan karakteristik KTI, 2) bentuk dan tujuan penulisan KTI, 3) sistematika penulisan KTI dan tips dan trik membuat KTI, dan 4) penyusunan dan penilaian KTI. Semua materi itu telah sesuai dengan tujuan yaitu untuk peningkatan dan pemahaman peserta terhadap penulisan karya tulis ilmiah guru.

Komponen ketiga adalah komponen tingkat kemudahan materi/handout. Jabaran mengenai 
komponen tersebut ada pada gambar di bawah ini.

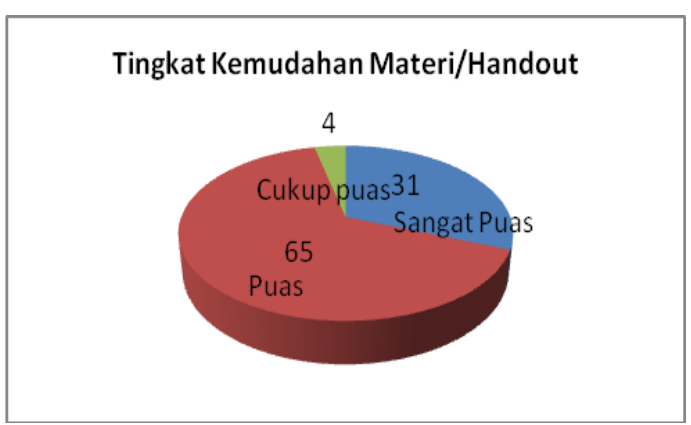

Gambar 3 Tingkat Kemudahan Materi/Handout

Berdasarkan diagram di atas dapat dilihat bahwa respon peserta pelatihan terkait dengan tingkat kemudahan materi/handout dalam pelatihan peserta pelatihan yang merasakan sangat puas sebanyak $31 \%$, merasa puas sebanyak $65 \%$, dan cukup puas $4 \%$.

Materi yang dituangkan dalam handout dikemas dengan menggunakan langkah-langkah rinci bagaimana cara menulis karya tulis ilmiah yang layak untuk dipublikasikan. Sehingga memudahkan peserta pelatihan dalam memahami langkah-langkah menulis KTI.

Komponen keempat adalah komponen kualitas urutan penyajian.

Available at

http://journal.unj.ac.id/unj/index.php/jpm
Jabaran mengenai komponen tersebut ada pada gambar di bawah ini.

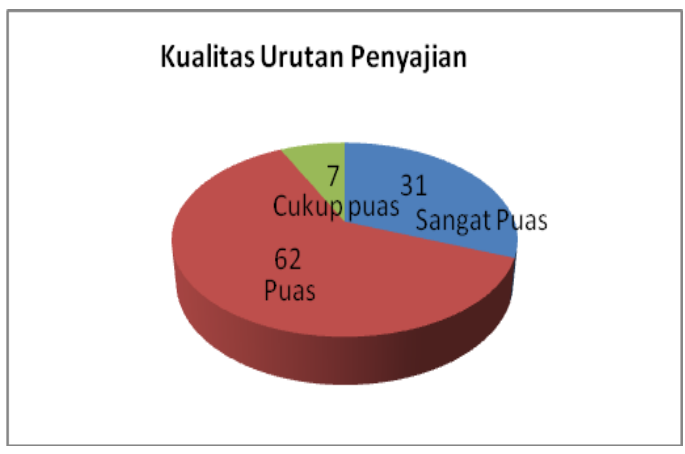

Gambar 4 Kualitas Urutan Penyajian

Berdasarkan diagram di atas dapat dilihat bahwa respon peserta pelatihan terkait dengan kualitas urutan penyajian dalam pelatihan peserta pelatihan yang merasakan sangat puas sebanyak $31 \%$, merasa puas sebanyak $62 \%$, dan cukup puas $7 \%$.

Kepuasan peserta pelatihan sebanyak $62 \%$ menggambarkan bahwa materi yang disajikan sudah sesuai dengan urutan atau langkah-langkah penulisan KTI. Materi yang disusun sesuai urutan dapat memudahkan peserta dalam memahami cara penulisan KTI yang benar.

Komponen kelima adalah komponen kecukupam latihan dalam materi. Jabaran mengenai komponen tersebut ada pada gambar di bawah ini.

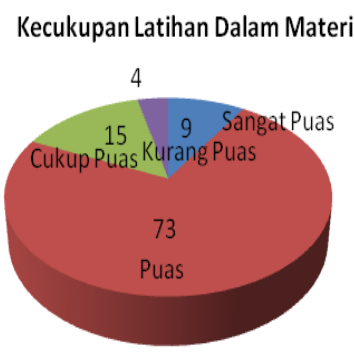


Gambar 5 Kecukupan Latihan Dalam Materi

Berdasarkan diagram di atas dapat dilihat bahwa respon peserta pelatihan terkait dengan kecukupan latihan dalam materi dalam pelatihan peserta pelatihan yang merasakan sangat puas sebanyak 9\%, merasa puas sebanyak $73 \%$, cukup puas $15 \%$, dan kurang puas $4 \%$.

Persentase puas pada kecukupan latihan menggambarkan bahwa waktu yang diberikan oleh tim PKM sangat cukup dalam mengembangkan tulisan yang telah dibawa oleh peserta. Setelah materi disampaikan oleh tim PKM, maka peserta wajib memperbaiki tulisannya masing-masing yang kemudian artikel tersebut dapat dipublikasikan di jurnal ilmiah.

Komponen keenam adalah komponen kesempatan dalam mendapatkan umpan balik. Jabaran

Available at

http://journal.unj.ac.id/unj/index.php/jpm mengenai komponen tersebut ada pada gambar di bawah ini.

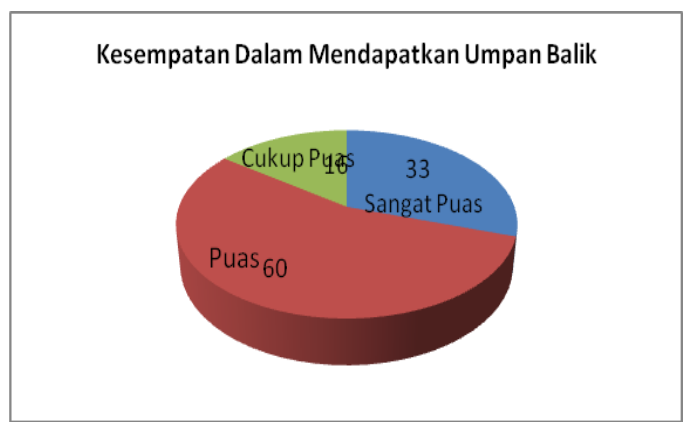

Gambar 6 Kesempatan Dalam Mendapatkan Umpan Balik

Berdasarkan diagram di atas dapat dilihat bahwa respon peserta pelatihan terkait dengan kesempatan dalam mendapatkan umpan balik dalam pelatihan peserta pelatihan yang merasakan sangat puas sebanyak 33\%, merasa puas sebanyak $60 \%$, dan cukup puas $16 \%$.

Peserta merasa puas terhadap umpan balik yang diberikan oleh tim PKM, karena peserta membutuhkan bimbingan pada saat memperbaiki artikel ilmiahnya masing-masing.

Komponen ketujuh adalah komponen kesempatan dalam meningkatkan skill. Jabaran mengenai komponen tersebut ada pada gambar di bawah ini.

Kesempatan Meningkatkan Skill

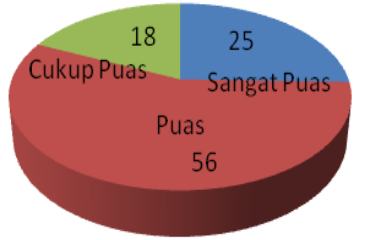


Gambar 7 Kesempatan Meningkatkan Skill

Berdasarkan diagram di atas dapat dilihat bahwa respon peserta pelatihan terkait dengan kesempatan meningkatkan skill dalam pelatihan peserta pelatihan yang merasakan sangat puas sebanyak $25 \%$, merasa puas sebanyak $56 \%$, dan cukup puas $18 \%$.

Dengan adanya pelatihan ini, peserta yang mayoritas guru merasa terbantu karena peserta mempunyai wadah untuk memasukkan artikel ilmiah mereka yang pada akhirnya dapat dipublikasikan dalam jurnal ilmiah dan dapat digunakan sebagai kenaikan pangkat/jabatan guru.

2) Aspek Narasumber

Aspek kedua adalah aspek narasumber. Tiap-tiap komponen dalam aspek akan dijabarkan dalam gambar dibawah ini.

Komponen pertama adalah komponen narasumber yang kompeten di bidang presentasi ilmiah. Jabaran mengenai komponen tersebut ada pada gambar di bawah ini.

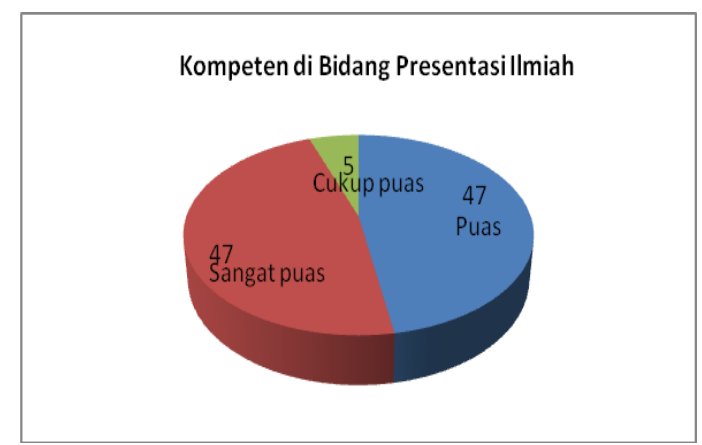

Gambar 8 Kompeten di Bidang Presentasi Ilmiah

Berdasarkan diagram di atas dapat dilihat bahwa respon peserta pelatihan terkait dengan narasumber yang kompeten di bidang presentasi ilmiah dalam pelatihan peserta pelatihan yang merasakan sangat puas sebanyak $47 \%$, merasa puas sebanyak $47 \%$, dan cukup puas $5 \%$.

Tim PKM yang menjadi narasumber merupakan dosen yang mempunyai latar belakang menulis ilmiah, seperti prosiding, jurnal dan publikasi ilmiah lainnya. Dengan melihat latar belakang tersebut, peserta yakin tentang kompetensi narasumber. Sehingga dengan adanya pelatihan KTI ini sangat membantu guru dalam mempublikasikan karya ilmiahnya.

Komponen kedua adalah komponen narasumber yang efisien 
dalam menjelaskan konsep materi Jabaran mengenai komponen tersebut ada pada gambar di bawah ini.

\section{Gambar 10 Gaya Bahasa Yang Komunikatif}

Berdasarkan diagram di atas dapat dilihat bahwa respon peserta pelatihan terkait dengan gaya bahasa narasumber yang komunikatif dalam pelatihan peserta pelatihan yang merasakan sangat puas sebanyak 64\%, merasa puas sebanyak $127 \%$, dan cukup Gambar 9 Kompeten di Bidang Presentasi Ilmiah

Berdasarkan diagram di atas dapat dilihat bahwa respon peserta pelatihan terkait dengan narasumber yang efisien dalam menjelaskan konsep materi dalam pelatihan peserta pelatihan yang merasakan sangat puas sebanyak $24 \%$, merasa puas sebanyak $71 \%$, dan cukup puas $5 \%$.

Komponen ketiga adalah komponen gaya bahasa yang komunikatif. Jabaran mengenai komponen tersebut ada pada gambar di bawah ini.

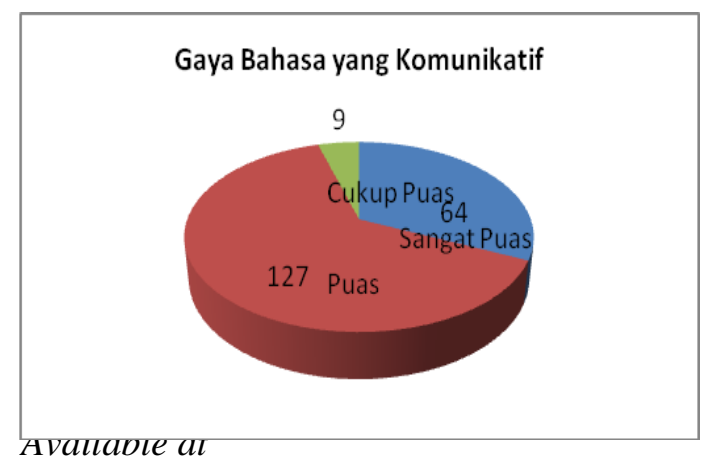

http://journal.unj.ac.id/unj/index.php/jpm puas $9 \%$.

Sebanyak $127 \%$ peserta pelatihan merasa puas dengan penyampaian narasumber terkait dengan materi KTI. Gaya bahasa yang komunikatif dan umpan balik yang diberikan oleh narasumber sangat membantu guru dalam memahami dan memperbaiki karya ilmiahnya masingmasing.

Komponen keempat adalah komponen narasumber yang menyenangkan/ variatif dalam menyempaikan materi. Jabaran mengenai komponen tersebut ada pada gambar di bawah ini.

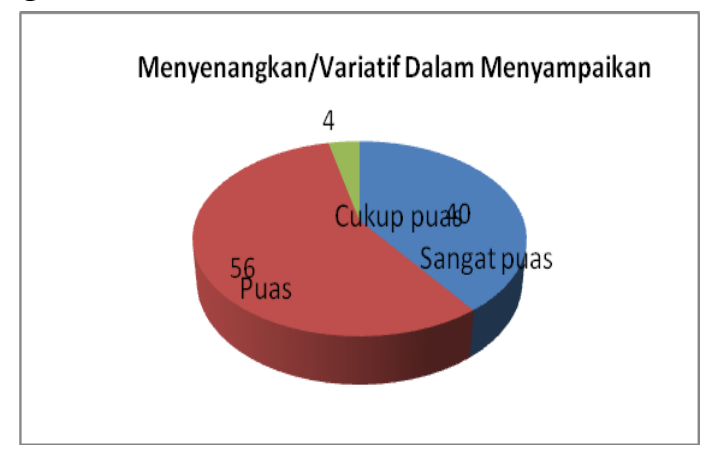




\section{Gambar 11 Menyenangkan/Variatif Dalam Menyampaikan Materi}

Berdasarkan diagram di atas dapat dilihat bahwa respon peserta pelatihan terkait dengan narasumber yang menyenangkan/variatif dalam menyampaikan pelatihan peserta pelatihan yang merasakan sangat puas sebanyak 40\%, merasa puas sebanyak $56 \%$, dan cukup puas $4 \%$.

Persentase kepuasan peserta sebanyak $56 \%$ terhadap aspek narasumber yang

menyenangkan/variatif dalam penyampaian materi dapat terlihat ketika banyak interaksi yang muncul pada saat proses pembimbingan KTI.

3) Aspek Umum

Aspek terakhir atau aspek ketiga adalah aspek umum. Tiap-tiap komponen dalam aspek akan dijabarkan dalam gambar dibawah ini.

$$
\text { Komponen pertama adalah }
$$
komponen layanan umum panitia. Jabaran mengenai komponen tersebut ada pada gambar di bawah ini.

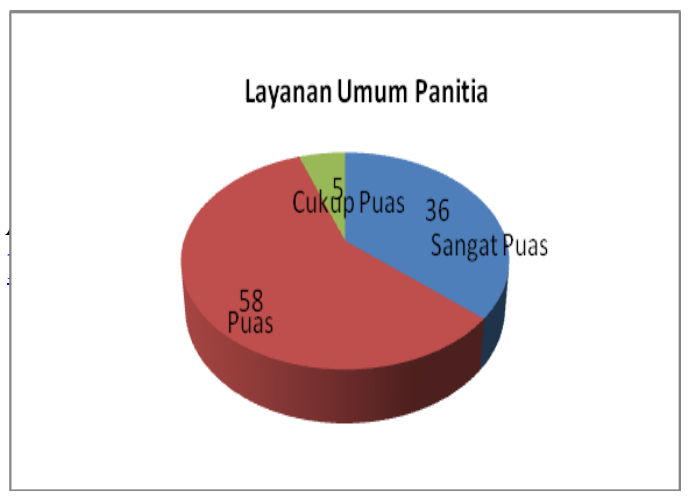

Gambar 11 Layanan Umum Panitia

Berdasarkan diagram di atas dapat dilihat bahwa respon peserta pelatihan terkait dengan layanan umum panitia pelatihan peserta pelatihan yang merasakan sangat puas sebanyak $36 \%$, merasa puas sebanyak $58 \%$, dan cukup puas $5 \%$.

Sebanyak $58 \%$ peserta pelatihan KTI merasa puas terhadap layanan umum panitia pelatihan. Hal ini terkait dengan mudahnya akses informasi pada saat pendaftaran, sarana dan prasarana, konsumsi, serta tindak lanjut pasca pelatihan.

Komponen kedua adalah komponen fasilitas dalam PKM. Jabaran mengenai komponen tersebut ada pada gambar di bawah ini.

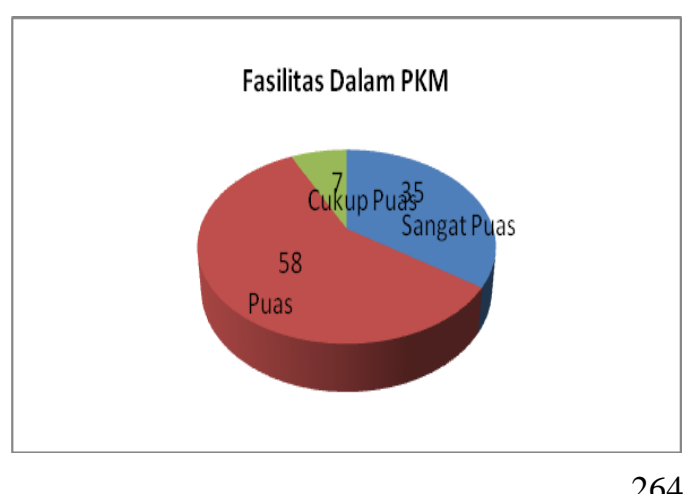




\section{Gambar12 Fasilitas Dalam PKM}

Berdasarkan diagram di atas dapat dilihat bahwa respon peserta pelatihan terkait dengan fasilitas dalam penelitian peserta pelatihan yang merasakan sangat puas sebanyak $35 \%$, merasa puas sebanyak $58 \%$, dan cukup puas $7 \%$.

Persentase peserta terkait fasilitas dalam PKM sebanyak 58\%. Hal ini menggambarkan bahwa peserta yaitu guru puas dengan fasilitas yang diberikan panitia PKM. Dalam hal ini fasiltas yang diberikan antara lain handout, seminat kit, dan konsumsi.

\section{KESIMPULAN DAN SARAN}

Dari hasil pembahasan yang telah dideskripsikan, dapat diambil beberapa simpulan, antara lain 1) pelaksanaan pelatihan penulisan KTI bagi Guru SMK di Jombang telah sesuai dengan tahapan yang telah direncanakan sebelumnya. yaitu pelatihan dilakukan pada dua mitra, yaitu MGMP Administrasi Perkantoran dan SMKN 1 Jombang, 2) secara keseluruhan respon peserta pelatihan

Available at

http://journal.unj.ac.id/unj/index.php/jpm
KTI ini merasakan sangat puas terhadap pelatihan yang diberikan terutama terkait dengan aspek pelaksanaan kegiatan, aspek narasumber, dan aspek umum.

Dari hasil pembahasan yang telah dideskripsikan, dapat diambil beberapa saran, antara lain 1) untuk meningkatkan pemahaman materi pelatihan KTI perlu dilakukan pembimbingan secara insentif dan praktik penulisan secara langsung, 2) diperlukan pelatihan lanjutan terkait dengan penulisan artikel ilmiah internasional, sehingga guru dapat memperluas pengetahuan tentang artikel ilmiah

\section{DAFTAR PUSTAKA}

Arikunto, 2007. Prosedur penelitian suatu pendekatan praktik. Jakarta: Rineka Aksara

Djuroto, Totok. 2014. Menulis artikel karya ilmiah. Bandung: Rosda Karya

Dwiloka, Bambang. 2005. Teknik Menulis Karya Ilmiah. Bandung: Rineka Cipta

Hakim, Adnan. 2015. "Contribution of Competence Teacher (Pedagogical, Personality, Professional Competence and Social) On the Performance of Learning". The 
International Journal of Engineering And Science (IJES). Volume 4 Issue 2 PP.01-12 ISSN: 2319 - 1813 ISSN: $2319-1805$. Diakses pada tanggal 28 Oktober 2017

Jejen, Musfah. 2011. Peningkatan Kompetensi Guru: Melalui Pelatihan dan Sumber Belajar Teori dan Praktik. Jakarta: Kencana

Maryadi. 2002. Pengertian Karya Ilmiah dalam Pembudayaan Penulisan Karya Ilmiah. Surakarta: UMS Press
Musfah, Jejen. 2011. Peningkatan Kompetensi Guru (Melalui Pelatihan dan Sumber Belajar Teori dan Praktik). Jakarta: Prenada Media Group.

Rif'an, Ali. 2012. Jenius Menulis dan Publikasi Karya Ilmiah. Solo: Kreasi Cerdas

Soehardjono. 2006. Menulis Karya Tulis Ilmiah. Jakarta: Remaja Cipta

\begin{tabular}{lrr} 
& 2010. & Prosedur \\
\hline $\begin{array}{l}\text { Penelitian. } \\
\text { Cipta }\end{array}$ & Jakarta: & Remaja
\end{tabular}

